\title{
БойКО В.О.
}

\section{COVID-19 та грип: основні віАмінності між кАінічними симптомами}

\begin{abstract}
Резюме. Даний огляд присвячений аналізу клінічних симптомів, диференціальній діагностиці COVID-19 та грипу для полегшення встановлення клінічного діагнозу при обох захворюваннях. Розвиток епідемії COVID-19 відбувався за експоненціальним ростом захворюваності через високу контагіозність вірусу, безсимптомне носійство. Ситуація ускладнювалася контагіозністю хворого в останні 2-3 доби інкубаційного періоду, що утруднювало своєчасну ізоляцію пацієнтів та контактних осіб. Уміру більш детального вивчення клінічного перебігу COVID-19 спектр ураження органів та систем постійно розширюється. Іноді прояви COVID-19 продовжуються навіть у періоді реконвалесиенції, що досить часто призводить до зниження працездатності та якості життя пацієнтів. У статті розглядаються неврологічні прояви, симптоми з боку шлунково-кишкового тракту й особливості пневмонії при COVID-19. Також продемонстровані клінічні особливості грипу та основні відмінності в клінічному перебігу від COVID-19. Ключові слова: COVID-19; грип; клінічні симптоми; диференціальна діагностика; огляд
\end{abstract}

Останнім десятиріччям відбувалось декілька спалахів коронавірусної інфекції, що були спричинені різними штамами коронавірусу (CoV). Спалах атипової пневмонії у 2002 році був викликаний вірусом SARS-CoV, близькосхідний коронавірусний респіраторний синдром, що вперше був зареєстрований у 2012 році, спричинений вірусом MERS-CoV [1, 2]. Наприкінці 2019 року в Ухані (Китай) вперше був ідентифікований новий коронавірус SARS-CoV2, що викликав спалах нової коронавірусної інфекції 2019 COVID-19 [3]. Через виникнення вперше на окремо взятій території та у всьому світі, швидке та значне поширення, відсутність засобів ефективного лікування та профілактики COVID-19, як й атипова пневмонія, коронавірус Близького Сходу, був внесений до списку емерджентних інфекцій.

У 2020 році розвиток епідемії відбувався за експоненціальним ростом захворюваності через високу контагіозність вірусу, безсимптомне носійство та відносно тривале зберігання збудника в оточуючому середовищі $[1,5,7]$.

COVID-19 характеризується найбільш агресивною передачею порівняно із SARS та MERS, але в той же час і значно меншою летальністю - 3,3 \% у середньо- му, тоді як при захворюваннях, що спричинені SARS та MERS, вона становила 9,6 та 34,4 \% відповідно [6, 8].

Всесвітня організація охорони здоров'я (ВОО3) 11 березня 2020 року оголосила про початок пандемії COVID-19. За даними BOO3, що надаються в щотижневій оперативній інформації, на 27.01.2021, за останній тиждень було зареєстровано 4,1 мільйона нових випадків, що на $15 \%$ нижче, ніж на попередньому тижні, а кількість смертей становила трохи менше 96 000, що мало відрізняється від попереднього тижня [4]. Таким чином, у світі на 01.02.2021 року підтверджено 103594874 випадки COVID-19 та 2239275 летальних випадків [9].

Звичайно, шо таке швидке поширення COVID-19 та відсутність ефективного етіотропного лікування спровокували панічні настрої та розгубленість у суспільстві, а введені карантинні обмеження з метою призупинки стрімкого росту захворюваності та перенавантаження медичної системи призвели ще й до масштабного економічного спаду в абсолютній більшості країн світу.

В Україні станом на 23.03.2021 року зареєстровано 1565732 випадки COVID-19, із них летальних 30 431, одужали 1268886 осіб [9]. Не менш важливими показниками є кількість госпіталізованих пацієнтів,

\footnotetext{
(c) «Oral and General Health», 2021

() Видавець Заславський 0.10. / Publisher Zaslavsky 0.Yu., 2021
}

Для кореспонденції: Бойко В.О., кандидат медичних наук, доцент кафедри інфекційних хвороб, Національний університет охорони здоров'я України імені П.Л. Шупика, вул. Дорогожицька, 9. м. Київ, 04112, Україна; e-mail: boykuscmu@gmail.com

For correspondence: V. Boyko, PhD, Associate Professor at the Department of infectious diseases, Shupyk National University of Public Health of Ukraine, Dorohozhytska st., 9, Kyiv, 04112, Ukraine; e-mail: boykuscmu@gmail.com

Full list of author information is available at the end of the article. 
адже це ті особи, у яких перебіг COVID-19 середньотяжкий (за наявності супутньої патології) або тяжкий, як визначено у Стандартах медичної допомоги «Коронавірусна хвороба COVID-19» [10].

Однак у холодний період року характерне підвищення також захворюваності і на інші гострі респіраторні вірусні інфекції (ГРВІ) та грип, які мають схожі клінічні симптоми з COVID-19. За даними Центру громадського здоров'я, станом на 14.03.2021 року на грип та ГРВІ з початку сезону (28.09.2020 року) перехворіло 9,9 \% населення країни, а інтенсивний показник захворюваності на грип та ГРВІ на 9,5 \% менше аналогічного періоду минулого сезону. Подібна ситуація спостерігається і в США, де з кінця вересня було підтверджено 925 випадків грипу проти 63975 в сезоні 2019-2020 [19]. Слід було очікувати, що карантинні обмеження суттєво вплинуть і на зниження захворюваності щодо інших ГРВІ та грипу.

Щодо COVID-19 та грипу існують чіткі алгоритми обстеження, що описані у відповідних стандартах та протоколах медичної допомоги [10, 13]. Але щодо ГРВІ іншої етіології доступних широкому загалу діагностичних методів обмаль, тому основний акцент необхідно робити на визначенні симптомів та синдромів, що допоможуть клінічно запідозрити те або інше захворювання.

Дуже часто ми чуємо, що COVID-19 та грип - це схожі захворювання як за частотою передачі, так і за клінічною картиною. Але такі твердження не відповідають дійсності. Швидкість поширення вірусу контролюється індексом репродукції (R), або кількістю осіб, яких може заразити один інфікований. Індекс репродукції SARS-CoV2 та вірусу грипу суттєво відрізняється, про що свідчать дані дослідників. Так, під час пандемії грипу у 2009 році R вірусу типу A (H1N1) становив 1,4-1,5 зі зниженням до 1,1-1,2 [16]. Під час епідемії грипу в Китаї у 2017-2018 рр., яку автори визначили як тяжку, R становив 1,53 для вірусів грипу A (H1N1, H3N2) та B (Victoria) [15]. Недостатнє охоплення вакцинацією населення та низька відповідність гемаглютинінів вірусів грипу А (H1N1 H3N2) та B (Victoria) епідемічним вірусам, що були запропоновані для вакцин під час цієї епідемії, дозволяють нам порівнювати R, що був визначений дослідниками, із SARS-CoV2. Перша відмінність щодо індексу репродукції SARS-CoV2 стосується суттєвої гетерогенності цього показника. Arif Billah зі співавт. на основі аналізу 42 досліджень визначили сумарний репродуктивний індекс за допомогою метааналізу, який становив 2,87. Тобто одна людина, інфікована SARS-CoV2, може заразити 2-3 людини. Дослідники показали, що репродуктивний індекс значно варіює навіть у межах однієї країни. Найвищий репродуктивний показник був зафіксований на круїзному лайнері Diamond Princess y Японії - 14,8. На рівні держав найбільш високі рівні $\mathrm{R}$ зафіксовано у Франції - 6,32, Германії - 6,07 та Icпанії - 3,56 [17]. Таким чином, доведено, що пацієнт із COVID-19 може інфікувати в 1,8-2 рази більшу кількість осіб у своєму оточенні, ніж хворий на грип, чим й обумовлена більш агресивна передача інфекції та карантинні обмежувальні заходи, що прийняті в більшості країн світу.
Відрізняється і період контагіозності в пацієнтів iз COVID-19 та грипом. Пацієнти можуть інфікувати оточуючих за 48 годин до появи клінічних ознак, із легким та помірним перебігом COVID-19 вони заразні максимум до 10 діб клінічних проявів, деякі із хворих із тяжкою формою або вираженим імунодефіцитом можуть бути заразні до 20 діб [18]. При грипі термін контагіозності дещо коротший -24 години до появи клінічних ознак та 5, рідше -7 діб клінічної маніфестації [19].

Інкубаційний період при грипі становить від 1 до 7 діб, у середньому 2-3 доби [19], тоді як при COVID-19 він триває від 2 до 14 діб, у середньому 5 діб [21]. Однак є дослідження, в яких у 97,5 \% пацієнтів із клінічно маніфестованими формами COVID-19 середній інкубаційний період визначений як 11,2 доби [22].

Розрізняють декілька клінічних варіантів COVID-19 [23]:

1. Гостра респіраторна вірусна інфекція.

2. Пневмонія без проявів дихальної недостатності.

3. Пневмонія з гострою дихальною недостатністю.

4. ГРДС (гострий респіраторний дистрес-синдром).

5. Сепсис.

6. Септичний (інфекційно-токсичний) шок.

На сьогодні достеменно відомо, що переважає легкий або помірний ступінь тяжкості - до $81 \%$ сумарно, тяжкий перебіг відмічався в $14 \%$ хворих та критичний - у 5 \% пацієнтів [21, 32].

Відомо, що тяжкий та критичний перебіг із розвитком ускладнень грипу значно частіше відмічається в таких групах пацієнтів [25, 26, 29]:

1. Вік понад 65 років.

2. Хронічні захворювання легень або хронічна обструктивна хвороба легень.

3. Хронічні серцево-судинні захворювання.

4. Цукровий діабет.

5. Хронічна ниркова недостатність.

6. Онкологічні захворювання.

7. Після нещодавно перенесеної трансплантації.

Абсолютна більшість дослідників наголошує на різноманітності клінічних ознак COVID-19, а діапазон систем та органів, які уражуються при цьому захворюванні, постійно розширюється [23-25, 38].

\section{Основні кАінічні прояви COVID-19}

П'ять симптомів, що виникають найчастіше в пацієнтів із COVID-19 при зверненні за медичною допомогою, визначені в систематичних оглядах та метааналізі клінічних досліджень у різних авторів (рис. 1) [12, 14, 38-41]. Найбільш поширеними симптомами у хворих на COVID-19 є лихоманка (> 90 \%), сухий кашель або з незначною кількістю харкотиння (>76\%), задишка, що виникає на 5-6-ту добу захворювання (> $53 \%$ ), виражена слабкість (> $51 \%$ ), міалгії (> 44 \%) [40, 41]. Рівень лихоманки може бути від субфебрильного до фебрильного, озноб відмічають лише $4 \%$ пацієнтів [12]. Задишка спочатку виникає при фізичному навантаженні, а в разі прогресування процесу з'являється і в спокої. Зниження сатурації в пацієнтів із COVID-19<92\% при вимірюванні пульсоксиметром є показанням до госпі- 
талізації [10]. Кашель у більшості пацієнтів надсадний, гучний, тривалий, непродуктивний [14]. Звертають на себе увагу слабкість та міалгії не тільки через частоту виявлення, а й через вираженість цих обох симптомів незалежно від наявності або рівня лихоманки [41]. На біль у м'язах спини та попереку припадає більше $60 \%$ всіх випадків міалгії [42], а інтенсивність болю настільки виражена, що заважає пацієнтам прийняти комфортне положення тулуба як протягом дня, так і вночі. Прояви з боку нервової системи також можна віднести до найбільш частих. Емоційна лабільність, підвищена дратівливість, безсоння, що виснажує, - симптоми, які зберігаються тривалий час навіть після одужання $[18,21]$. Зі значно меншою частотою виникають симптоми з боку шлунково-кишкового тракту (ШКТ), що описані нижче.

У загальному аналізі крові спостерігається лімфопенія: більше ніж у $70 \%$ випадків $<1,0 \times 10^{9} / л[30]$. Серед інших лабораторних змін звертають на себе увагу підвищення С-реактивного білка, подовження протромбінового часу, тромбоцитопенія, підвищення D-димеру [21].

\section{ШАунково-кишкові симптоми}

ШКТ із деякими органами, що експресують ангіотензинперетворюючий фермент 2 (АПФ-2), мають особливе значення для проникнення SARS-CoV2 у клітини-мішені [27]. Уже в лютому 2020 року Y. Song зі співавт. описували діарею як перший симптом COVID-19 на тлі лихоманки за відсутності інших проявів захворювання [28]. Хоча деякі автори вказують на невисоку частоту нудоти, блювання (5\%) та діареї $(3,8 \%)$ у 1099 пацієнтів, які лікувались від COVID-19 у стаціонарах Китаю [29], інші дослідження підтверджують статистичне значення симптомів із боку ШКТ як індикатора тяжкої форми захворювання [29, 30]. Відсутність або суттєве зниження апетиту розглядається як один з основних симптомів, що супроводжують COVID-19 [27]. Дійсно, часто пацієнти скаржаться на відсутність апетиту незалежно від наявності або відсутності лихоманки, причому це стосується і пиття, яке вкрай необхідне як елемент симптоматичного лікування. Лабораторні показники характеризуються підвищенням АлАТ та АсАТ у 20-22 \% хворих, рідше білірубіну - $10 \%$ випадків, при цьому значно частіше зміни відбуваються в пацієнтів із тяжкою формою COVID-19 [29].

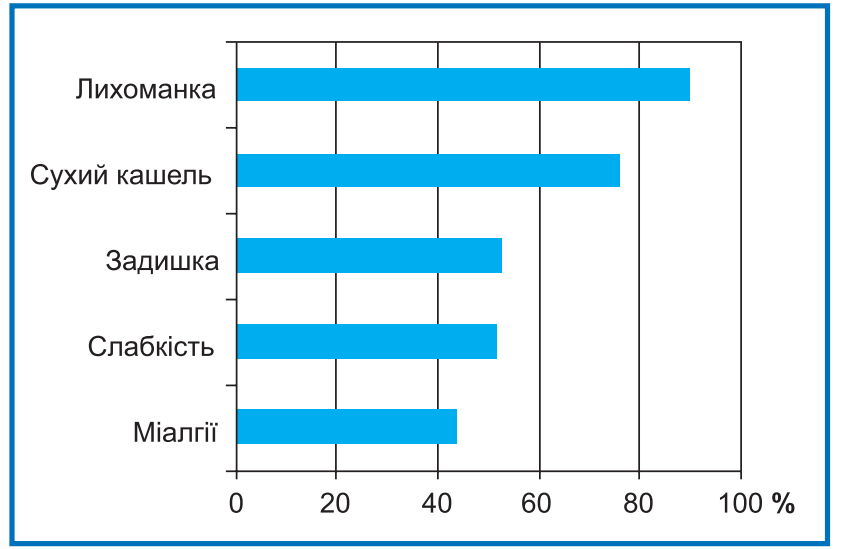

Рисунок 1. Найбільш часті клінічні симптоми в пацієнтів із COVID-19

\section{Ураження нервової системи}

Із розвитком епідемії та збільшенням кількості хворих медичні працівники стали помічати різноманітність неврологічних симптомів у пацієнтів із COVID-19, що не тільки з'являлись у розпал захворювання, а й передували появі типових симптомів [3336]. Важливі неврологічні прояви, що описані в літературних джерелах, відображені в табл. 1.

Лідируючі позиції за частотою проявів посідають такі симптоми, як аносмія (втрата нюху) або гіпоосмія (зниження нюху) та агевзія (втрата смаку) або гіпогевзія (зниження смакової чутливості) [36]. Важливо, що на відміну від інших ГРВІ ці ознаки не пов’язані з набряком слизової носоглотки, що спричиняють закладеність носа, або ринореєю [35]. Далі за частотою клінічних симптомів розташовані головний біль та запаморочення [33]. Неврологічні прояви розподіляють на центральні (головний біль, запаморочення, енцефаліт) та периферійні (втрата нюху та смаку, синдром Гійєна - Барре) [34].

Дуже часте питання, що задають нам пацієнти як при зверненні за допомогою, так і при виписці, - коли ж відновиться нюх. На це питання відповіли автори європейського багатоцентрового дослідження 1363 пацієнтів із COVID-19 [20]. По-перше, дослідники виявили, що аносмія або гіпоосмія переважають у хворих із легким $(54,7 \%)$ та помірним ступенем тяжкості $(36,6 \%)$ порівняно з тяжким або критичним станом (4,5-6,9 \%). Середня тривалість розладів нюху стано-

Таблиця 1. Неврологічні прояви при COVID-19

\begin{tabular}{|l|c|l|c|}
\hline \multicolumn{2}{|c|}{ Неврологічні прояви } \\
\hline \multicolumn{1}{|c|}{ Центральні [33, 37] } & \multicolumn{2}{c|}{ Периферійні [34, 36] } \\
\hline \multicolumn{1}{|c|}{ Симптом } & Частота, \% & \multicolumn{1}{c|}{ Частота, \% } \\
\hline Головний біль & $19-20$ & Аносмія & 79,6 \\
\hline Запаморочення & $17-19$ & Гіпоосмія & 20,4 \\
\hline $\begin{array}{l}\text { Порушення мозкового } \\
\text { кровообігу }\end{array}$ & $1-2$ & Гіпогевзія & 78,9 \\
\hline Порушення свідомості & $12-14$ & Агевзія & 21,1 \\
\hline Енцесралопатія & $2-4$ & Синдром Гійєна - Барре & $1-2$ \\
\hline
\end{tabular}


вила 21,6 \pm 17,9 дня. У 328 (24,1\%) пацієнтів, тобто в кожного четвертого хворого на COVID-19, нюх так і не відновився через 60 діб після початку дисфункції, а в 4,7 \% випадків нюх не відновився навіть через 6 місяців. Тому заспокоюйте своїх пацієнтів, пояснюйте їм, що дисфункція нюху та смаку не свідчить про тяжкий перебіг захворювання, а тривале збереження цього стану є типовою ознакою COVID-19, а не ускладненням.

\section{Пневмонія при COVID-19}

Дані щодо частоти пневмонії у хворих на COVID-19 досить відрізняються. На початку 2020 року A. Wannarat зі співавт. повідомляли про виявлення в $39 \%$ випадків пневмонії серед 193 пацієнтів із середнім часом від початку захворювання до її виявлення 7 діб [43]. Однак при подальшому поширенні захворювання у світі дані щодо частоти пневмонії при COVID-19 дещо змінились. D. Wang зі співавт. при спостереженні 138 пацієнтів із COVID-19 вказують на виявлення змін на комп'ютерній томограмі (КT) у всіх $100 \%$ хворих [26]. І.В. Маннанова зі співавт. повідомили про наявність пневмонії у $81,5 \%$ випадків серед 227 хворих на COVID-19, із дихальною недостатністю різного ступеня тяжкості - у 73,1\% $(\mathrm{n}=166)$ [12].

Але в той же час у дослідників немає розбіжностей щодо переважно двобічного характеру ураження не менше ніж у $80 \%$ пацієнтів [12, 26, 43, 44].

Зміни за типом «матового скла», що виявляються на KT у пацієнтів із COVID-19 (табл. 2), відповідно до градації за об’ємом ураження легеневої тканини визначають ступінь тяжкості пневмонії [45]. Але тільки в зіставленні змін на КТ і клініко-лабораторних даних ми можемо визначати ступінь тяжкості перебігу захворювання. У пацієнтів з ураженням легень $5 \%$ може бути сатурація $<90 \%$, а клінічна картина може характеризуватись ознаками дихальної недостатності, тоді як в інших хворих при $\mathrm{KT}_{3}$ сатурація $>95 \%$.

Таблиця 2. Візуальна оцінка приблизного обсягу ущільненої легеневої тканини в обох легенях

\begin{tabular}{|c|c|}
\hline Градація & $\begin{array}{c}\text { Виявлені зміни та відсоток } \\
\text { ураження тканини легень }\end{array}$ \\
\hline $\mathrm{KT}_{0}$ & Відсутність характерних проявів \\
\hline $\mathrm{KT}_{1}$ & Мінімальний обсяг < 25\% \\
\hline $\mathrm{KT}_{2}$ & Середній обсяг 25-50\% \\
\hline $\mathrm{KT}_{3}$ & Значний обсяг 50-75\% \\
\hline $\mathrm{KT}_{4}$ & Критичний обсяг > 75\% \\
\hline
\end{tabular}

I.В. Маннанова зі співавт. продемонстрували у своїй роботі, що градації КТ3 та КТ4 виявлені зі значно нижчою частотою (відповідно у 18,9 та $0,4 \%$ пацієнтів), ніж KT1 (у 24,7 \% випадків) та КT2 (у $31,3 \%$ хворих), а 14,5\% випадків належали до групи KT0 [12].

Важливо пояснювати пацієнтам, що об’єм ураження легеневої тканини не завжди відповідає тяжкості

Таблиця 3. Диференціальна діагностика COVID-19 та грипу

\begin{tabular}{|c|c|c|}
\hline $\begin{array}{c}\text { Симптоми } \\
\text { захворювання }\end{array}$ & COVID-19 & Грип \\
\hline Початок захворювання & Поступовий & Раптовий \\
\hline Лихоманка & $\begin{array}{c}\text { Часто як субфребрильна, } \\
\text { так і фребрильна }\end{array}$ & Завжди переважає фребрильна \\
\hline Міалгії & $\begin{array}{c}\text { Виражені, локалізація - спина, } \\
\text { поперек, рідше - шия, } \\
\text { нижні кінцівки }\end{array}$ & $\begin{array}{c}\text { Помірні, } \\
\text { локалізація - нижні кінцівки, } \\
\text { рідше - поперек }\end{array}$ \\
\hline Артралгії & Помірні, рідко виникають & Помірні, часто виникають \\
\hline Головний біль & Виражений, дисууний & $\begin{array}{c}\text { Помірний, біль у лобовій частині } \\
\text { голови, в очних яблуках }\end{array}$ \\
\hline Нежить & Не типовий & Типовий \\
\hline Аносмія, агевзія & Виникають часто & Не характерні \\
\hline Слабкість & $\begin{array}{c}\text { Тривала, } \\
\text { виражена навіть у період } \\
\text { реконвалесценції }\end{array}$ & $\begin{array}{c}\text { Виражена в період розпалу } \\
\text { клінічних проявів }\end{array}$ \\
\hline Кашель & $\begin{array}{c}\text { Часто сухий або з незначною } \\
\text { кількістю мокроти }\end{array}$ & Часто сухий \\
\hline Задишка & $\begin{array}{c}\text { Характерна, } \\
\text { виникає на 5-ту - 7-му добу } \\
\text { захворювання }\end{array}$ & Не характерна \\
\hline Діарея & Іноді виникає & Рідко в дорослих \\
\hline Втрата апетиту & Дуже часто, виражена & $\begin{array}{c}\text { Виражена в період розпалу } \\
\text { клінічних проявів }\end{array}$ \\
\hline Емоційна лабільність, безсоння & Досить часто виникають & Рідко виникають \\
\hline
\end{tabular}




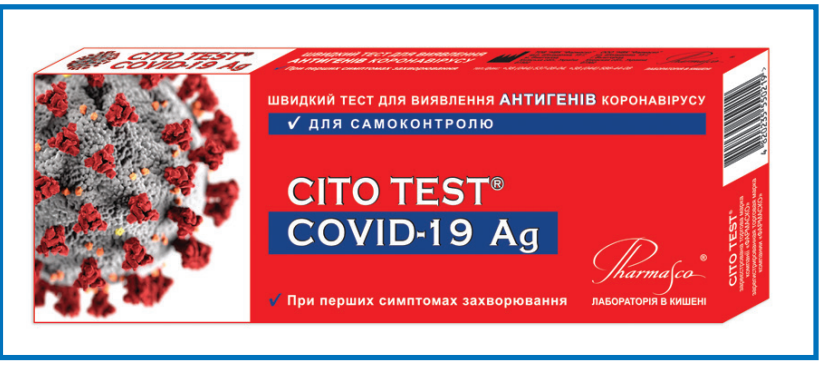

Рисунок 2. Швидкий тест для виявлення антигену SARS-CoV2

клінічного перебігу і не впливає на тактику ведення пацієнта. А тому клінічні показання мають бути основним чинником до призначення лікарем такого методу обстеження, як КТ або рентгенографія органів грудної клітки.

\section{Аиференціальна Аіагностика COVID-19 та грипу}

Пандемія інфекції, спричиненої вірусом SARSCoV2, спричинила паніку серед населення різних країн світу. Підвищення температури тіла одразу викликає занепокоєння та страх, що це ознака виключно COVID-19, однак не слід забувати і про інші гострі респіраторні вірусні інфекції, у тому числі грип, різні штами якого також можуть викликати захворювання iз симптомами інтоксикації та ураження легень. Диференціальна діагностика COVID-19 та грипу відображена в табл. 3 на основі різних літературних джерел [46-49].

Основними ознаками грипу є раптовий початок, різке підвищення температури тіла, як правило, до $38,0{ }^{\circ} \mathrm{C}$ та вище, іноді лихоманка, що супроводжується ознобом, виражена слабкість у розпал клінічних симптомів, сухий кашель, першіння та дряпання за грудиною (пацієнт дуже яскраво описує цей прояв і показує локалізацію виключно за грудиною), сухий кашель та нежить (перші 3-4 доби турбує закладеність носа, а 3 4-5-ї доби з'являються виділення), іноді осиплість голосу (саме осиплість, а не афонія). Турбує головний біль, хворий чітко вказує локалізацію болю: лобна частина, очні яблука. Температура знижується досить різко - за типом критичного лізису на 5-6-ту добу захворювання. Місцеві прояви при грипі обумовлені вибірковим ураженням епітелію респіраторного тракту, переважно трахеї. Ураження ШКТ у дорослих відбувається дуже рідко, але іноді виникає діарея [19, 47, 48].

\section{Застосування швиАКих тестів А^я Аіагностики гострих респіраторних інфекцій}

Центральну роль у контролі спалахів грипу та COVID-19 відіграє діагностичне тестування, основними засадами якого мають бути достатня чутливість та специфічність методів, швидкість виконання, доступність.

Заходи, що скорочують час між тестуванням та отриманням результатів, є вкрай важливими для мінімізації подальшої передачі інфекції в популяції. Про-

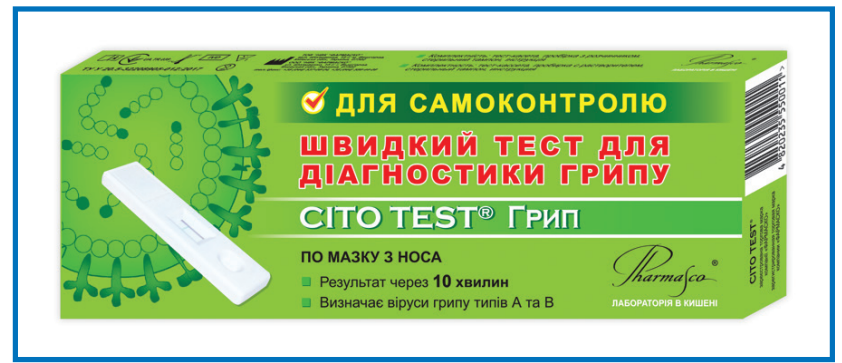

Рисунок 3. Швидкий тест для виявлення антигенів вірусів грипу А та В

тестувати та ізолювати кожен підозрілий випадок на COVID-19 - саме це дозволить уповільнити, а з часом і зупинити епідемію цієї емерджентної інфекції.

Швидкі тести на визначення антигену SARS-CoV2 та грипу A/B i $є$ такими заходами, що дозволяють за мінімальну кількість часу (15-20 хвилин) запідозрити в пацієнта COVID-19 або грип, у тому числі з малосимптомними формами, провести диференціальну діагностику між цими двома захворюваннями з огляду на схожість клінічної картини, вони не потребують наявності спеціальної лабораторії.

Експрес-тест на визначення антигену SARS-CoV2 (рис. 2) виявляє компоненти вірусу в мазках із носоглотки з першого дня клінічних симптомів і протягом першого тижня захворювання, тобто в період максимальної контагіозності хворих. Чутливість цього методу становить 90,4 \%, а специфічність 99,5\%. Категорії осіб, яким може проводитись обстеження швидкими тестами для виявлення антигенy SARS-CoV2, як і дії в разі отримання позитивного та негативного результатів, чітко визначені в стандартах медичної допомоги «Коронавірусна хвороба (COVID-19)» [10].

Експрес-тест на визначення антигенів вірусів грипу А та В (рис. 3) у мазках із носа також дозволяє виявити інфекцію на ранній стадії, коли паці$€$ нт $є$ максимально заразним для оточуючих, але в даному випадку цей період становить 48-72 години від появи перших симптомів. Уніфікований клінічний протокол визначає категорії осіб, що підлягають тестуванню на грип та інтерпретацію результатів експрес-тесту на антиген у пацієнтів із грипоподібними захворюваннями [13].

Таким чином, COVID-19 в умовах сьогодення є захворюванням із вираженим поліморфізмом клінічних проявів. Швидке поширення інфекції у всьому світі та відсутність етіотропного лікування спричинили паніку серед людей. Підсилює панічні настрої перенавантаження медичної системи, що призводить до обмеження доступу до медичної допомоги. У той же час багато сумнівних джерел інформації подають суперечливі, на жаль, часто неправдиві повідомлення. Через недооцінку ситуації з COVID-19, з одного боку (небажання носити маски, слідувати карантинним обмеженням та ін.), та переоцінку, з іншого боку (намагання потрапити до стаціонару навіть при легкому або середньотяжкому перебігу та ін.), у досить складній ситуації опинились і медичні працівники на початку епідемії. 
Дана стаття надає інформацію про клінічний перебіг COVID-19 та диференціальну діагностику з грипом для полегшення встановлення клінічного діагнозу лікарями різних спеціальностей, які зараз працюють у лікарнях, перепрофільованих під одну нозологію.

Конфлікт інтересів. Автор заявляє про відсутність конфлікту інтересів та власної фінансової зацікавленості при підготовці даної статті.

\section{Список мітератури}

1. Qun L., Xuhua G., Peng W., Xiaoye W., Lei Z., Yeqing T. et al. Early transmission dynamics in Wuhan, China, of novel Coronavirusinfected pneumonia. New Engl. J. Med. [Internet]. 2020 Mar [cited 2021, Feb 1]. 382. 1199-1207. Available from: https://www.nejm.org/ doi/full/10.1056/nejmoa2001316.

2. Wu Z., McGoogan J.M. Characteristics of and important lessons from the coronavirus disease 2019 (COVID-19) outbreak in China: summary of a report of 72314 cases from the Chinese Center for Disease Control and Prevention. JAMA. 2020. 323. 1239-1242.

3. Phelan A.L., Katz R., Gostin L.O. The novel coronavirus originating in Wuhan, China: challenges for global health governance. JAMA. 2020. 323. 709-710.

4. World Health Organization. Coronavirus disease (COVID-19) Weekly Epidemiological Update and Weekly Operational Update [Internet]. Geneva: World Health Organization, 2021 [updated 2021, January 26; cited 2021, Jan 30]. Available from: https://www.who. int/emergencies/diseases/novel-coronavirus-2019/situation-reports.

5. Hirano T., Murakami M. COVID-19: A New Virus, but a Familiar Receptor and Cytokine Release Syndrome. Immunity [Internet]. 2020 May [cited 2021, Feb 1]. 19. 52(5). 731-733. Available from: https://doi.org/10.1016/j.immuni.2020.04.003. PMID: 32325025; PMCID: PMC7175868.

6. Silvio DP. COVID-19 Compared to Other Pandemic Diseases. Rambam Maimonides Med J [Internet]. 2020 Jul [cited 2021, Feb 1]. 11(3). e0027 Available from: https://www.ncbi.nlm.nih.gov/pmc/articles/PMC7426550. PMID: 32792043; PMCID: PMC7426550.

7. Liu Y., Yan L.M., Wan L., Xiang T.X., Le A., Liu J.M. et al. Viral dynamics in mild and severe cases of COVID-19. Lancet Infect Dis [Internet]. 2020 Jun [cited 2021, Feb 1]. 20(6). 656-657.

8. Elrashdy F., Redwan E.M., Uversky V.N. Why COVID-19 Transmission Is More Efficient and Aggressive Than Viral Transmission in Previous Coronavirus Epidemics? Biomolecules [Internet]. 2020 Sep [cited 2021, Feb 1]. Available from: https://doi. org/10.3390/biom 100913129.

9. Worldometers. COVID-19 Coronavirus Pandemic [Internet]. United States: Worldometers, 2021 [updated 2021, Jan 31; cited 2021, Jan 31]. Available from: https://www.worldometers.info/coronavirus.

10. Міністерство охорони здоров'я України. Наказ МОЗ України від 17.09.2020 № 2122 «Про внесення змін до Стандартів медичної допомоги «Коронавірусна хвороба (COVID-19)» [Інтернет]. Киї: Міністерство охорони здоров'я України, 2020 [Оновлено 2020, вер. 17; иитовано 2021, січ. 31]. Доступно: https://moz.gov.ua/uploads/5/26180-dn_2122_17_09_2020_dod_ standart_final.pdf.

11. Центр громадського здоров'я. Захворюваність на грип та ГРВІ в Україні [Інтернет]. Київ: Центр громадського здоров'я, 2021 [Оновлено 2021, січ. 24; цитовано 2021, січ. 31]. Доступно: https://phc.org.ua/kontrol-zakhvoryuvan/inshi-infekciyni-zakhvo- ryuvannya/monitoring-i-ocinka/zakhvoryuvanist-na-grip-ta-grvi-vukraini.

12. Маннанова И.В., Семенов В.Т., Понежева Ж.Б. Клинико-лабораторная характеристика COVID-19. Российский медицинский журнал [Интернет]. 2021 Янв [Цитировано 2021, янв. 31]. Доступно: https://www.rmj.ru/articles/infektsionnye_bolezni/kliniko-laboratornaya-kharakteristika-covid-19.

13. Міністерство охорони здоров'я України. Уніфікований клінічний протокол первинної, вторинної (спеціалізованої) медичної допомоги дорослим та дітям «Грип». Наказ МОз України № 499 від 16.07.2014 року [Інтернет]. Київ: Міністерство охорони здоров'я Украӥни, 2020 [Оновлено 2014, лип. 17; цитовано 2021, січ. 31]. Доступно: https://ips.ligazakon.net/document/view/ MOZ23599?ed=2014_07_16\&an=31.

14. Дуда О.К., Вега А.Р., Бойко В.О., Печінка А.М., Коцюбайло Л.П. Клінічні особливості COVID-19 у дорослих. Здоров'я суспільства. 2020. 1(9). 19-22.

15. Xiaofang F., Yuqing Zh., Jie W., Xiaoxiao L., Cheng D., Chenyang H. et al. Severe Seasonal Influenza Epidemic During 2017-2018 in China After the 2009 Pandemic Influenza: A Modeling Study. Infectious Microbes \& Diseases. 2019. 1(1). 20-26.

16. Cowling J.B., Lau M.S., Lai-Ming H., Chuang Sh.K., Tsang T., Liu S.H. et al. The effective reproduction number of pandemic influenza: Prospective estimation. Epidemiology. 2010 Nov. 21(6). 842-846.

17. Billah A., Miah M., Khan N. Reproductive number of coronavirus: A systematic review and meta-analysis based on global level evidence. PLoS ONE [Internet]. 2020 Nov [cited 2021, Feb 1]. Available from: https://doi.org/10.1371/journal.pone.0242128.

18. Centers for Disease Control and Prevention. Duration of Isolation and Precautions for Adults with COVID-19 [Internet]. Washington: Centers for Disease Control and Prevention, 2020 [updated 2020, Oct 19; cited 2021, Jan 31]. Available from: https://www.cdc. gov/coronavirus/2019-ncov/hcp/duration-isolation.html.

19. Centers for Disease Control and Prevention. How Flu Spreads [Internet]. Washington: Centers for Disease Control and Prevention, 2018 [updated 2018, Aug 27; cited 2021, Jan 31]. Available from: https://www.cdc.gov/flu/about/disease/spread.htm.

20. Lechien J.A., Chiesa E., Beckers E., Mustin V., Ducarme M., Journe F. et al. Prevalence and 6-month recovery of olfactory dysfunction: a multicentre study of 1363 COVID-19 patients. Journal of internal medicine [Internet]. 2021 Jan [cited 2021, Feb 1]. Available from: https://doi.org/10.1111/joim. 13209.

21. Centers for Disease Control and Prevention. Interim clinical guidance for management of patients with confirmed coronavirus disease (COVID-19) [Internet]. Washington: Centers for Disease Control and Prevention; 2020 [updated 2020, Dec 8; cited 2021, Jan 31]. Available from: https://www.cdc.gov/coronavirus/2019-ncov/hcp/ clinical-guidance-management-patients.html.

22. Lauer S.A., Grantz K.H., Bi Q. The Incubation Period of Coronavirus Disease 2019 (COVID-19) From Publicly Reported Confirmed Cases: Estimation and Application. Ann. Intern. Med. 2020, May 5. 172(9). 577-582.

23. Баздырев Е.Д. Коронавирусная инфекция - актуальная проблема ХХІ века. Комплексные проблемы сердечно-сосудистых заболеваний. 2020. 9(2). 6-16.

24. Cennimo D.J. Coronavirus Disease 2019 (COVID-19) Clinical Presentation [Internet]. New York: Medscape, 2021 [updated 2021, Jan 28; cited 2021, Jan 31]. Available from:. https://emedicine. medscape.com/article/2500114-clinical. 
25. Aliabadi F., Ajami M., Pazoki-Toroudi H. Why does COVID-19 pathology have several clinical forms? Bio Assays [Internet]. 2020 Nov [cited 2021, Feb 1]. 42(12). 000198. Available from: https://doi.org/10.1002/bies.202000198.

26. Wang D., Нu B., Нu C., Zhu F., Liu X., Zhang J. et al. Clinical Characteristics of 138 Hospitalized Patients With 2019 Novel Coronavirus-Infected Pneumonia in Wuhan, China. JAMA. 2020, Mar 17. 323(11). 1061-1069.

27. Chunxiang M., Yingzi C., Hu Zh. COVID-19 and the Digestive System. The American Journal of Gastroenterology [Internet]. $2020 \mathrm{Jul}$ [cited 2021, Feb 1]. 115(7). 1003-1006. Available from: https://doi.org/10.14309/ajg.0000000000000691.

28. Song Y., Liu P., Shi X.L., Chu Y.L., Zhang J., Xia J. et al. SARS-CoV-2 induced diarrhea as onset symptom in patient with COVID-19. Gut [Internet]. 2020 Jun [cited 2021, Feb 1]. 69(6). 11431144. Available from: https://doi.org/10.1136/gutjnl-2020-320891.

29. Guan W., Ni Z.Y., Hu Y., Liang W.H. Clinical Characteristics of Coronavirus Disease 2019 in China. N. Engl. J. Med. 2020. 382. $1708-1720$.

30. Wang D., Hu B., Hu C. Clinical Characteristics of 138 Hospitalized Patients With 2019 Novel Coronavirus-Infected Pneumonia in Wuhan, China. JAMA. 2020. 323(11). 1061-1069.

31. Holshue M.L., DeBolt C., Lindquist S. First case of 2019 novel coronavirus in the United States. N. Engl. J. Med. 2020. 382(10). 929-936.

32. Wu Z., McGoogan J.M. Characteristics of and Important Lessons From the Coronavirus Disease 2019 (COVID-19) Outbreak in China: Summary of a Report of 72314 Cases From the Chinese Center for Disease Control and Prevention. JAMA. 2020, Feb 24. 323(13). 1239-1242.

33. Ahmad I., Rathore F.A. Neurological manifestations and complications of COVID-19: A literature review. J. Clin. Neurosci. 2020 Jul. 77. 8-12.

34. Corona T., Rodríguez-Violante M., Delgado-García G. Neurological manifestations in coronavirus disease 2019. Gac. Med. Mex. 2020. 156(4). 317-320.

35. Gklinos P. Neurological manifestations of COVID-19: a review of what we know so far. J. Neurol. 2020 Sep. 267(9). 24852489.

36. Lechien J.R., Chiesa-Estomba C.M., De Siati D.R., Horoi M., Le Bon S.D., Rodriguez A. et al. Olfactory and gustatory dysfunctions as a clinical presentation of mild-to-moderate forms of the coronavirus disease (COVID-19): a multicenter European study. Eur. Arch. Otorhinolaryngol. 2020 Aug. 277(8). 22512261.

37. Helms J., Kremer S., Merdji H., Clere-Jehl R., Schenck M., Kummerlen C. Neurologic Features in Severe SARS-CoV-2 Infection. N. Engl. J. Med. 2020. 382(23). 2268-2270

38. Huang C., Wang Y., Li X. et al. Clinical features of patients infected with 2019 novel coronavirus in Wuhan, China. Lancet. 2020 Feb. 395. 497-506.

39. Zhang J.Y., Lee K.S., Ang L.W., Leo Y.S., Young B.E. Risk Factors of Severe Disease and Efficacy of Treatment in Patients Infected with COVID-19: A Systematic Review, Meta-Analysis and Meta-Regression Analysis. Clin. Infect. Dis. 2020, Nov 19. 71(16). 2199-2206.
40. International Severe Acute Respiratory and Emerging Infections Consortium (ISARIC). COVID-19 Report [Internet]. Washington: ISARIC, 2020 [updated 2020, May 19; cited 2021, Jan 31]. Available from: https://media.tghn.org/medialibrary/2020/05/ ISARIC_Data_Platform_COVID-19_Report_19MAY20.pdf.

41. Docherty A.B., Harrison E.M., Green C.A., Hardwick H.E., Pius R., Norman L. et al. Features of 20133 UK patients in hospital with covid-19 using the ISARIC WHO Clinical Characterisation Protocol: prospective observational cohort study. BMJ [Internet]. 2020 May [cited 2021, Jan 31]. 369. m1985. Available from: https://doi. org/10.1136/bmj.m 1985.

42. Sadiye M., Bilinc D.K., Afitap I., Celal U., Sacit I., Onur I. Clinical presentations of pain in patients with COVID-19 infection. Ir. J. Med. Sci. [Internet]. 2020 Nov [cited 2021, Jan 31]. Available from: https://doi.org/10.1007/s11845-020-02433-x.

43. Pongpirul W.A., Wiboonchutikul S., Charoenpong L., Panitantum N., Vachiraphan A. et al. Clinical course and potential predictive factors for pneumonia of adult patients with Coronavirus Disease 2019 (COVID-19): A retrospective observational analysis of 193 confirmed cases in Thailand. PLOS Neglected Tropical Diseases [Internet]. 2020, Oct 16 [cited 2021, Jan 31]. 14(10). e0008806. Available from: https://doi.org/10.1371/journal.pntd.0008806.

44. Jiong W., Xiaojia W., Wenbing Z., Dajing G., Zheng F., Chen L. et al. Chest CT Findings in Patients With Coronavirus Disease 2019 and Its Relationship With Clinical Features. Invest Radiol [Internet]. 2020 May [cited 2021 Jan]. 55(5). 257261. Available from: https://www.ncbi.nlm.nih.gov/pmc/articles/ PMC7147284.

45. Inui S., Fujikawa A., Jitsu M., Kunishima N., Watanabe S., Suzuki Y., Umeda S., Uwabe Y. Chest CT Findings in Cases from the Cruise Ship Diamond Princess with Coronavirus Disease (COVID-19). Radiology: Cardiothoracic Imaging [Internet]. 2020, Mar 17 [cited 2021, Jan 30]. 2(2). 1-7. Available from: https://doi. org/10.1148/ryct.2020200110.

46. NHS. Coronavirus (COVID-19) symptoms [Internet]. London: NHS, 2021 [updated 2021, Jan 21; cited 2021, Jan 31]. Available from: https://www.nhs.uk/conditions/coronavirus-covid-19/ symptoms.

47. NHS. Flu [Internet]. London: NHS, 2019 [updated 2019, Aug 6; cited 2021, Jan 31]. Available from: https://www.nhs.uk/conditions/flu.

48. World Health Organization. $Q \& A$ : influenza and COVID-19 - similarities and differences [Internet]. Geneva: World Health Organization; 2020 [updated 2020, Mar 17; cited 2021, Jan 30]. Available from: https://www.who.int/westernpacific/news/q-a-detail/q-a-similarities-and-differences-covid19-and-influenza.

49. Dowdall M., Stewart K. Differential diagnosis: cold, flu or COVID-19? The Pharmaceutical Journal [Internet]. 2020, Sep 24 [cited 2021, Jan 30]. Available at: https://www.pharmaceutical-journal.com/cpd-and-learning/learning-article/differential-diagnosiscold-flu-or-covid-19/20208379.article.

Отримано/Received 11.01.2021 Рецензовано/Revised 26.01.2021 Прийнято до друку/Accepted 29.01.2021 
V.O. Boyko

Shupyk National University of Public Health of Ukraine, Kyiv, Ukraine

\section{COVID-19 and influenza: main differences between clinical symptoms}

Abstract. This review analyzes the clinical symptoms, differential diagnosis of COVID-19 and influenza to facilitate clinical diagnosis of both diseases. The development of the COVID-19 epidemic occurred with an exponential growth of the incidence due to the high contagiousness of the virus, asymptomatic carriage. The situation was aggravated by the contagiousness of the patient in the last 2-3 days of the incubation period (before clinical manifestations), which made it difficult to isolate patients and contacts in a timely. The spectrum of damage to the organs and systems is constantly expanding with a more de- tailed study of the clinical course of COVID-19. Sometimes, the manifestations of COVID-19 persist even during the period of convalescence, which cause a decrease in the performance and quality of life of patients. The article discusses neurological manifestations, gastrointestinal symptoms and features of pneumonia in COVID-19. The clinical features of influenza and the main differences in the clinical course from COVID-19 are also demonstrated.

Keywords: COVID-19; influenza; clinical symptoms; differential diagnosis; review

\section{Бойко В.A.}

Национальный университет зАравоохранения Украины имени П.А. Шупика, г. Киев, Украина

\section{COVID-19 и грипп: основные отАичия межАУ кАиническими симптомами}

Резюме. Данный обзор посвящен анализу клинических симптомов, дифференциальной диагностике COVID-19 и гриппа для облегчения установления клинического диагноза при обоих заболеваниях. Развитие эпидемии COVID-19 проходило по экспоненциальному росту заболеваемости из-за высокой контагиозности вируса, бессимптомного носительства. Ситуация осложнялась контагиозностью больного в последние 2-3 суток инкубационного периода, что затрудняло своевременную изоляцию пациентов и контактных лиц. По мере более детального изучения клинического течения COVID-19 спектр поражения органов и систем постоянно расширяется. Иногда проявления COVID-19 продолжаются даже в периоде реконвалесценции, что довольно часто приводит к снижению работоспособности и качества жизни пациентов. В статье рассматриваются неврологические проявления, симптомы со стороны желудочнокишечного тракта и особенности пневмонии при COVID-19. Также продемонстрированы клинические особенности гриппа и основные отличия в клиническом течении от COVID-19. Ключевые слова: COVID-19; грипп; клинические симптомы; дифференциальная диагностика; обзор 